American Journal of Environmental Sciences 5 (2): 187-196, 2009

ISSN 1553-345X

(C) 2009 Science Publications

\title{
Management Policy in and Typology of State Park Systems
}

\author{
${ }^{1}$ Lowell Caneday, ${ }^{1}$ Debra Jordan and ${ }^{2}$ Yating Liang \\ ${ }^{1}$ Leisure Studies, Oklahoma State University, 180 Colvin Center, Stillwater, OK 74078 \\ ${ }^{2}$ Department of Health, Physical Education and Recreation \\ Missouri State University, 901 S. National Avenue, Springfield, MO 65897
}

\begin{abstract}
Problem statement: Parks, with particular emphasis on national and state parks, host varied interactions between human and natural systems. In particular, state park systems manage important resources related to quality of life and also are mainstays in tourism, economic development and preservation of heritage and conservation of ecosystems. Management of these parks and the human activity occurring in them is an integral component of environmental science. Approach: This research focused on identifying the legal mandates, management policies and practices that define park operations in various states within the United States. This research was a precursor to benchmarking state park systems, essential to identifying similar and dissimilar systems for the purpose of identifying benchmarking partners. Utilizing the annual information exchange of the National Association of State Park Directors, the researchers conducted a K-means cluster analysis of state park systems across the United States. Results: A seven-cluster solution was found to be the best description of the fifty state park systems. Twenty five of thirty characteristics were identified as being significant factors in defining clusters of state parks. These significant factors included: (1) number of properties, (2) number of designated state parks, (3) number of recreation areas, (4) number of environmental areas, (5) number of scientific areas, (6) number of forests, (7) number of trails and (8) miles of trails. Interestingly, mission statements and types of oversight governmental agency were not defining factors in determining clusters of state parks. Conclusion/Recommendations: This cluster analysis of state parks is important as a foundation for benchmarking state park systems, permitting comparison with similar and dissimilar systems. It is also important for consideration of marketing state parks to visitors who desire particular experiences in specific environments. This analysis provided a better understanding of interactions between human activity and natural systems, offering management insight for improved practices.
\end{abstract}

Key words: State parks, benchmarking, park management, cluster analysis

\section{INTRODUCTION}

In contemporary American society we wrestle with the concept of park. A precise definition is unlikely given the great variety of properties and locations with that designation. Over time a park has meant a hunting reserve, a garden, a neighborhood playground, or a stadium $^{[13]}$. For the purpose of this article, parks are defined as tracts of tax-supported land and water, established primarily for the benefit and enjoyment of the public and maintained essentially for outdoor recreation activities ${ }^{[13]}$. Parks come in all shapes and sizes and are classified in a variety of ways. In some situations, designations for parks, such as national park and state park, indicate the governmental level administering the area. In most cases, national and state parks include legal mandates and management policies that address the natural environment. As a result, most parks, with particular emphasis on national and state parks, become host sites for varied interactions between human and natural systems. Further, these state park systems manage important resources related to quality of life and also are mainstays in tourism, economic development, preservation of heritage and conservation of ecosystems. As such, management of these parks and the human activity occurring in them is an integral component of environmental science.

This research focused on identifying the legal mandates, management policies and practices that define park operations in various states within the United States. Several states have attempted to benchmark their state park system utilizing comparisons with other state park systems. To conduct such benchmarking from an informed basis, it is

Corresponding Author: Lowell Caneday, Leisure Studies, Oklahoma State University, 180 Colvin Center, Stillwater, OK 74078 
essential to know whether a particular system is like or unlike the system under review.

History of parks in the United States: Landrum ${ }^{[8]}$ suggests that the development of parks in the United States was closely associated with a range of societal changes in 19th century. The first parks in the United States were the expressions of urban planning influenced by the design of European cities. As urban planning developed in the latter half of the 19th century, maintaining open space was frequently incorporated into planning for the increasing need for public recreation. As the nation flourished economically and its population became more urbanized, an increasing need for outdoor recreation was expressed. At the same time, citizens were increasingly interested in nature and in preserving some of the country's magnificent sceneries. These aspects of social awareness stimulated the American public park movement. As this was occurring, a number of national parks were established for the purposes of preservation of nature and provision of public recreation.

The first national park in the United States (as well as in the world) was Yellowstone National Park, established in 1872. By 1916, 14 national parks had been established ${ }^{[9]}$ and the National Park Service Organic Act of 1916 created the National Park Service (NPS). This national park system has had tremendous influence on the development of state parks in the United States. While most states had established a state park system by the early 1900s, a few states did not initiate development of their state parks until the 1930s. In fact, some western states still had very limited state park systems by the middle of the 20th century. By the turn of the 21st century, all states and several US territories had developed park systems. The national parks were the model for the design and development of many state parks.

The economic depression in 1930s was a boon to park development, especially the development of state parks. Federal aid programs such as the Civilian Corps Conservation (CCC), the Public Works Administration (PWA), the Works Progress Administration (WPA) and the Civil Works Administration (CWA) put people to work in the parks. Federal aid stimulated an unprecedented level of park development in the United States.

The CCC contributed more to state park development than any other federal relief program ${ }^{[2]}$. Eight states acquired their first state parks during the CCC era. By the time the CCC program ended in 1942, the CCC had built or improved 405 state parks in
43 states $^{[8]}$. The other two programs that directly benefited state parks were the Recreational Demonstration Areas, which contributed almost 300,000 acres of new state park land and the 1936 Park, Parkway and Recreation Area Study Act, which provided the continued basis of ongoing intergovernmental efforts between federal and state to improve the planning and development of state parks ${ }^{[8]}$.

During World War II, although the operation and expansion of state parks were disrupted, the state parks movement continued to develop and mature ${ }^{[8]}$. State parks managed to add 92 new areas and about 350,000 acres overall ${ }^{[8]}$. After World War II, development of state parks rebounded. State park attendance was on the rise, more park personnel were employed and park expenditures increased. Renewed emphasis was placed on parkland acquisition. In 1946, over 1,500 areas were categorized as state parks, by 1950 , the figure increased by 200 , with total acreage exceeding 2.4 million acres ${ }^{[7]}$.

The decades of 1950 s and 1960s were the golden era of outdoor recreation in the United States. During this time the development of state parks gained tremendous support from the federal government. The Outdoor Recreation Resources Review Commission (ORRRC) was established in 1958 and was charged with studying the national needs and supply of outdoor recreation. The report of Outdoor Recreation Resources Review Commission (ORRRC), Outdoor Recreation for America, was completed in 1962. The most significant impact that report made on the development of state parks was the call for a federal grants-in-aid program to assist the outdoor recreation planning and the acquisition and development of additional parks and recreation areas.

The Bureau of Outdoor Recreation was established in 1962 to coordinate and provide assistance to states for outdoor recreation programs ${ }^{[4,9]}$. The Land and Water Conservation Fund (LWCF) Act in 1964 once again prompted a level of expansion of state parks that had not been seen since the 1930s. The LWCF was the most important fund for acquiring and developing state and local parklands ${ }^{[2,12]}$. The funds could be used for three legislated purposes: (1) Comprehensive recreation planning, (2) Land acquisition and (3) Development of outdoor recreation facilities. Grants could not be used to maintain existing facilities. Federal money would pay half of the cost of an approved project and the recipient state would pay the other half. From 1965 to $1987, \$ 3.2$ billion in federal grants were appropriated to fund state and local projects nationwide ${ }^{[2]}$. 
The decade of the 1960s was also the time that the role of state parks started to change in a fundamental way $^{[8]}$. For most of the 20th century, the primary goal of the state park movement was to acquire properties for public enjoyment. Then, starting during the 1960s, the focus shifted to systematic and comprehensive planning and implementation of policies and programs to meet the increasing and diversified demand for recreation. When Alaska added their state park system in 1970, the state parks picture of the United States was complete. Every state now has a state park system which has played a vital role in protecting the United States' legacy and public parklands, as well as providing various recreation opportunities for people.

Defining State Parks in the United States: McLean ${ }^{[10]}$ defines state parks as "... areas containing a number of coordinated programs for the preservation of natural and/or cultural resources and provision of a variety of outdoor recreation opportunities". However, state park agencies often administer a broad variety of areas in addition to state parks. The Annual Information Exchange (AIX) published by the National Association of State Park Directors (NASPD) identifies additional areas that are in the "state park estate", which include state parks, recreation areas, natural areas, historical areas, environmental education areas, scientific areas, state forests, state fish and wildlife areas, other areas and miscellaneous areas ${ }^{[10,11]}$. A state park system consists of state parks and the additional areas mentioned above.

Frederick Law Olmsted proposed principles that guided the California State Parks in determining the areas to be included in an ultimate, comprehensive park system in the early 20th century. These principles had been useful in guiding the development of state park systems in many other states. These principles espoused by Olmsted are: (1) such areas should be sufficiently distinctive and notable to interest people from distant parts of a state to visit and use them, (2) the areas contain scenic and recreation resources of kinds not likely to be well conserved and made available under private ownership for the enjoyment of ordinary people, (3) they provide enjoyment that local parks, national parks may not provide otherwise and (4) they are so geographically distributed as to comprise a wide and representative variety of properties for the whole state and with a reasonable assortment of them equitably accessible to people in each part of the state.

Tilden $^{[14]}$ classified state parks into six categories: parks, monuments, recreation areas, beaches, parkways and waysides. $\mathrm{He}^{[14]}$ defined a state park as "...a relatively spacious area of outstanding scenic or wilderness character oftentimes containing also significant historical, archeological, ecological, geological and other scientific values, preserved as nearly as possible in their original or natural condition and providing opportunity for appropriate types of recreation where such will not destroy or impair the features and values to be preserved. Commercial exploitation of resources is prohibited".

State parks fill a niche between smaller urban parks and the larger national parks. State parks provide vastly different experiences than can be found in city parks and they provide similar types of recreational opportunities as those provided in the national parks. Therefore, state parks serve as close-to-home substitutes for national parks and as complements to urban parks. Further, state parks focus on environmental resource-based recreation opportunities, a trait that often separates them from urban recreation parks. As a result, state parks have become primary locations for interaction between humans and nature. These state park properties have become vestiges of the natural environment, now managed to sustain and improve the quality of life for residents and visitors in each state.

The landscape architect, Harold Caparn ${ }^{[3]}$, suggested several principles for the development of state parks. First, state parks should not necessarily be confined to the rare and most beautiful scenery in a particular state or ecosystem. State parks may be areas of beauty and significance, though not in the highest degree. They provide opportunities for physical recreation to inhabitants of the nearby population centers. Second, the preservation of clean, readily accessible, enjoyable beaches and lakeshores is important for state parks. Third, the three major service areas that should be provided in state parks include (1) the preservation of places of historical importance to the state, (2) available acreage for people nearby to afford picnicking and hiking and (3) the maintenance of park surroundings.

Many early park planners suggested that state parks should be close to large population areas and should be a meeting-place under ideal conditions for all people, an educational place, a recreational place, a health center, a weekend resort for all with change of climate, scenery and people, where millions can go, a scenic advertising medium for a State. A National Conference on State Parks report suggests that, State parks were essentially conservation projects...acquired and established by the States primarily to preserve outstanding examples of the State's scenic, scientific 
and cultural features...should not be considered as recreation facilities in the sense of city playgrounds ${ }^{[8]}$.

Tremendous differences exist among state parks in resources, size, types of administration, available facilities, financing, visitation and management concepts. The resources in state parks systems are as diverse as the states, ranging from deserts in Nevada, lakes in Minnesota, to mountains in the Carolinas and ocean beaches in California. The size of state park systems ranges from the smallest (Rhode Island State Parks) of 9,000 acres, to the largest (Alaska State Parks) of over three million acres. The number of annual visitors varies from nearly one million to over eight million.

In addition to differences in visitation, state park systems are managed under different administrative agencies across states. For example, Alabama State Parks is under an environmental super-agency, the Department of Conservation and Natural Resources. Oklahoma State Parks is a part of a smaller state agency division, the Oklahoma Tourism and Recreation Department within a Department of Commerce. The Arizona system of state parks is under a distinct parks department, Arizona State Parks. Some state park systems are managed through agencies that are aligned with tourism, commerce and economic development. Other state park systems are aligned with agencies that emphasize fish, wildlife and habitat preservation. Still other state park systems are aligned with agencies that focus on environmental conservation and natural resources.

Several factors may contribute to these differences including history, political trends, inter-government relationships and prevailing management philosophy ${ }^{[5]}$. Yet, state park systems have many similarities. For instance, state parks are usually relatively close to urban areas, easily accessible to dense population areas. Many state parks provide a variety of recreation opportunities such as camping, picnicking, hiking, swimming and fishing as well as overnight stays in rustic cabins and resort-type lodges. In addition, many state parks provide diverse developed facilities such as golf courses, swimming pools, visitor centers and restaurants.

\section{MATERIALS AND METHODS}

Methodology Utilized to Determine Typology: To examine the various approaches to state park systems across the United States, which can facilitate better understanding of human-nature interactions, the researchers engaged in a study designed to identify benchmarking partners among state parks. One of the essential principles in benchmarking is to identify like and unlike comparative systems, thus, a cluster analysis was utilized to identify the typology of state park systems. Once the typology has been established, it is possible to compare one system with others that can then serve as benchmarking partners. This can facilitate learning from others and assist with implementation of what is learned into one's own operation.

Cluster analysis is a method of grouping objects of a similar kind into respective and meaningful categories. The primary reason for the use of cluster analysis is to discover groups of similar entities in a sample data ${ }^{[1]}$. Cluster analysis is used most frequently when researchers do not have a priori hypotheses and are still in the exploratory phase of research.

In this study, the researchers selected and utilized the K-means cluster analysis process. Aldenderfer and Blashfield $^{[1]}$ refer to this method as an iterative partitioning method. K-means clustering splits a set of data into a selected number of groups by maximizing variation between factors relative to variation within factors. K-means cluster analysis attempts to identify relatively homogeneous groups of cases based on selected characteristics ${ }^{[6]}$. Furthermore, unlike hierarchical methods, K-means cluster analysis produces single-rank clusters that are not nested and, therefore, not part of a hierarchy.

The data used in the K-means cluster analysis were based on the 2004 Annual Information Exchange (AIX) data provided by the National Association of State Park Directors (NASPD). The Annual Information Exchange (AIX) is the primary source of data available to state park directors and researchers, dealing exclusively with state parks ${ }^{[11]}$. The National Association of State Park Directors (NASPD) publishes the AIX each year. The AIX questionnaire is a 19-page survey that includes data for seven areas concerning state parks: (1) Inventory of areas, (2) Types of facilities, (3) Visitation and use, (4) Capital improvement, (5) Financing, (6) personnel and (7) Support groups.

The AIX questionnaire is mailed every year to the 50 state park directors in the United States and designated individuals complete the instrument. The data are compared to each previous year's data to ensure accuracy ${ }^{[11]}$. In this study, 30 quantitative characteristics that reflected the major features of state park systems from the 2004 AIX were selected for the K-means cluster analysis. These 30 characteristics included five aspects: (1) Property characteristics, (2) Amenity characteristics, (3) Visitor characteristics, (4) operational characteristics and (5) Personnel 
Am. J. Environ. Sci., 5 (2): 187-196, 2009

characteristics. Each of these aspects reported detail on as many as 12 individual factors. Because the factors utilized different scales, the data were standardized before the K-means cluster analysis was performed. The standardized scores, $\mathrm{z}$-scores, were used in the $\mathrm{K}$ means cluster analysis.

The K-means cluster analysis divided the 50 state park systems into different groups according to the number of the clusters that were specified during the analysis. For example, a four-cluster solution divided the 50 state park systems into four groups and a fivecluster solution divided the 50 state park systems into five groups.

\section{RESULTS}

Typology of state parks and defining characteristics: The researchers explored a four-cluster solution, a fivecluster solution, a six-cluster solution, a seven-cluster solution, an eight-cluster solution, a nine-cluster solution and a ten-cluster solution. After comparing these solutions, the researchers determined that the seven-cluster solution was the most appropriate solution for the study. The four-, five- and six-cluster solutions were not chosen because these solutions were too general to reflect the distinct characteristics of each cluster. The eight-, nine- and ten-cluster solutions were not selected because the clusters were too discrete to reflect a cohesive group membership. In fact, several individual states were separated in the eight-, nine- and ten-cluster solutions. It should be noted that even with the two- and three-cluster solutions California and New York separated immediately from all other state park systems. The results of the K-means cluster analysis are shown in Table 1.

In addition to utilizing the AIX data, the researchers compared the mission statements of the 50 state park systems and the type of agencies in which the 50 state park systems were housed. The results indicated that these elements were not significant in determining the clusters. To test the stability of the clusters, the researchers analyzed the AIX data from the previous year (2003) and found consistency across the years among the clusters of state park systems.

The first group defined by the analysis included five state park systems. This group was named "Rural Western Park Systems", despite the fact that New Hampshire was identified as one member of the cluster. The state park systems in this group were relatively small in total acreage, with an average of about 120,000 acres. Among their properties were a small number of "state park" designations totaling less than $25 \%$ of the total property, on average.
Table 1: Seven-cluster solution and membership of clusters

\begin{tabular}{|c|c|c|}
\hline Cluster & $\begin{array}{l}\text { State park systems } \\
\text { (distance from the } \\
\text { cluster center) }\end{array}$ & $\begin{array}{l}\text { Total No. in } \\
\text { the cluster }\end{array}$ \\
\hline 1 & $\begin{array}{l}\text { Rural western park systems } \\
\text { CO (3.975), ID (3.379), } \\
\text { MT (6.219), NH (2.031), } \\
\text { ND ( } 2.000)\end{array}$ & 5 \\
\hline 2 & $\begin{array}{l}\text { Traditional resource park systems } \\
\text { AK (6.570), AZ (2.405), } \\
\text { AR (2.167), CT (2.762), } \\
\text { DE (1.981), HI (1.536), } \\
\text { KS (2.635), LA (2.244), } \\
\text { ME (2.785), MA(3.051), } \\
\text { MN (4.762), MS (1.973), } \\
\text { NE (3.290), NV (1.589), } \\
\text { NJ (2.171), NM (2.405), } \\
\text { NC (1.633), PA (6.365), } \\
\text { RI (1.896), SC (1.710), } \\
\text { UT (1.726), VE (2.475), } \\
\text { VA (2.586), WI }(2.162), \\
\text { WY (1.822) }\end{array}$ & 25 \\
\hline 3 & $\begin{array}{l}\text { Park systems developed } \\
\text { and staffed for tourism } \\
\text { AL }(2.485) \text {, GA }(2.436) \text {, } \\
\text { IN }(2.820), \text { KY }(5.265) \text {, } \\
\text { OH }(4.846), \text { OK }(3.868) \text {, } \\
\text { SD }(3.112), \text { TN }(4.094) \text {, } \\
\text { WV }(2.259)\end{array}$ & 9 \\
\hline 4 & $\begin{array}{l}\text { Populous, resource-based } \\
\text { park systems } \\
\text { FL (6.002), IL (5.854), } \\
\text { MI (3.487), MO (3.689), } \\
\text { OR (2.953), TX (4.262), } \\
\text { WA (3.751) }\end{array}$ & 7 \\
\hline 5 & California CA (0.000) & 1 \\
\hline 6 & $\begin{array}{l}\text { New York } \\
\text { NY }(0.000)\end{array}$ & 1 \\
\hline 7 & $\begin{array}{l}\text { Isolated small state park } \\
\text { systems } \\
\text { IA (4.211), MD (4.211) }\end{array}$ & 2 \\
\hline
\end{tabular}

These state park systems did not have amenities such as lodges, golf courses, or restaurants, although they had cabins on their properties. State park usage was light, with annual visitation of slightly over four million. Day use visitors were overwhelmingly the majority of the visitors (over 90\%). Most of these state park systems were supported by a variety of dedicated funds. The operational budget was small to medium, ranging from 2 million dollars to 27 million dollars. Most of these state park systems had fewer than 100 field positions, with an average of one field staff member for every two properties.

Twenty-five state park systems comprised the second cluster. This group was characterized as Traditional Resource park systems, which had an average acreage of nearly 250,000 acres per state. These state park systems identified a variety of property titles including such designations as recreation areas, 
natural areas, historical areas and "state park" designations. The state park designations constituted nearly $50 \%$ of the total number of properties. Most of these state park systems had cabins, but they tended not to have other developed amenities such as lodges, restaurants, or golf courses. The total number of visitors in these systems was approximately seven million annually. The operational budget of these state park systems was moderate, with an average of 20 million dollars. An average of two field staff members were assigned to each park property.

Nine state park systems belonged to the third cluster, which was characterized as Developed and Staffed for Tourism. In these systems, state park designations constituted the majority (about 70\%) of the total property. These state park systems included a number of cabins and other amenities such as lodges, restaurants, retail stores, shops and golf courses. Some parks in this cluster included high-end development such as airports, cable television connections and internet provision. The number of annual visitors averaged 18 million and most of these park systems did not utilize entry fees. The average operational budget was large, at 47 million dollars. Further, these park systems averaged more than seven field staff members on each property.

The fourth group included seven state park systems, which were classified as Populous, Resourcebased park systems. These systems had a large number of properties, averaging over 140, with one-third designated as state park. There were more trails in these park systems, averaging five designated trails per property. These state park systems had a number of developed amenities, including an average per system of more than 170 cabins, four lodges, four restaurants and one golf course. The average operational budget was considered large, topping 50 million dollars. Among these seven state park systems, six are in the top 20 most populous states in the United States. Therefore, it was not surprising that these park systems were heavily used, with annual visitors of over 28 million. An average of three field staff members were assigned to each property.

The fifth group and sixth groups were single member clusters, with California State Parks and New York State Parks in each group, respectively. Interestingly, both systems fell out as single member clusters in all of the cluster solutions. This indicates that California State Parks and the New York State Parks were so unique that they were completely distinct from other state park systems.

California State Parks is a large, comprehensive system with over 250 properties including a variety of areas in addition to state park designations, these include recreation areas, natural areas and historical areas. This single-member cluster was identified as California. The system included almost 1.5 million acres of land and almost 2000 trails. The system provided a variety of amenities: 60 cabins, 5 lodges, 14 restaurants and three golf courses. The California State Parks system received more than 80 million visitors annually. It had a 290 million dollar operational budget with numerous dedicated revenue sources. The system had approximately four field staff members per property.

New York State Parks had the largest number of properties of all the states. This cluster was characterized as small-staffed, complex and comprehensive and was identified as "New York." The system had over 860 properties with a great variety of property designations. The total acreage topped 1.5 million acres. The system operated over 750 cabins, four lodges, 28 restaurants and 19 golf courses and received over 50 million visitors annually. The New York State Parks system had a 160 million dollar operational budget with numerous dedicated revenue sources. Interestingly, they had a very small number of staff members per property, with an average of one field staff member per five properties. This implies a reliance on a great number of contracted laborers for the state park system.

The last cluster included two state park systems: Iowa State Parks and Maryland State Parks and was labeled "Isolated Small State Park System". This cluster had 100 properties on average, with one third of those properties designated as "state parks". The total acreage of property was over 160,000 acres and only two trails existed in the park systems. The two systems operated over 200 cabins and one restaurant, but no lodges or golf courses, annual visitation averaged over 12 million with a heavy concentration of day visitors. The operational budget was approximately 27 million dollars, with many dedicated revenue sources. Neither of the two systems utilized entry fees and the field staff averaged two per property.

Significant Descriptors of Clusters: In addition to performing K-means cluster analysis to group the 50 state park systems and identifying state park systems that were similar and dissimilar from each other, the researchers conducted an analysis of variance (ANOVA) to discover the significant descriptors among the 30 characteristics in determining the clusters. The alpha level was set at 0.01 . 
Am. J. Environ. Sci., 5 (2): 187-196, 2009

Table 2: ANOVA source table for property descriptors (Group A) $(\mathrm{N}=50)$

\begin{tabular}{|c|c|c|c|c|c|c|}
\hline & & Sum of squares & Df & Mean square & $\mathrm{F}$ & Sig. \\
\hline \multirow[t]{3}{*}{ Number of properties } & Between groups & 668745.176 & 6 & 111457.529 & 30.890 & $<0.001^{*}$ \\
\hline & Within groups & 155155.244 & 43 & 3608.261 & & \\
\hline & Total & 823900.420 & 49 & & & \\
\hline \multirow[t]{3}{*}{ Number of parks } & Between groups & 21551.226 & 6 & 3591.871 & 7.245 & $<0.001 *$ \\
\hline & Within groups & 21316.774 & 43 & 495.739 & & \\
\hline & Total & 42868.000 & 49 & & & \\
\hline \multirow[t]{3}{*}{ Number of recreation areas } & Between groups & 13469.031 & 6 & 2244.839 & 4.409 & $0.001 *$ \\
\hline & Within groups & 21894.889 & 43 & 509.183 & & \\
\hline & Total & 35363.920 & 49 & & & \\
\hline \multirow[t]{3}{*}{ Number of natural areas } & Between groups & 4292.911 & 6 & 715.485 & 2.349 & 0.047 \\
\hline & Within groups & 13097.269 & 43 & 304.588 & & \\
\hline & Total & 17390.180 & 49 & & & \\
\hline \multirow[t]{3}{*}{ Number of historical areas } & Between groups & 3068.418 & 6 & 511.403 & 3.105 & 0.013 \\
\hline & Within groups & 7081.582 & 43 & 164.688 & & \\
\hline & Total & 10150.000 & 49 & & & \\
\hline \multirow[t]{3}{*}{ Number of environmental areas } & Between groups & 70.980 & 6 & 11.830 & 10.869 & $<0.001 *$ \\
\hline & Within groups & 46.800 & 43 & 1.088 & & \\
\hline & Total & 117.780 & 49 & & & \\
\hline \multicolumn{7}{|l|}{ Significance level at $\alpha=0.01$} \\
\hline & & Sum of squares & df & Mean square & $\mathrm{F}$ & $\mathrm{Sig}$ \\
\hline \multirow{3}{*}{ No. of scientific areas } & Between Groups & 3833.564 & $\frac{11}{6}$ & 638.927 & 6.650 & $<0.001 *$ \\
\hline & Within groups & 4131.716 & 43 & 96.086 & & \\
\hline & Total & 7965.280 & 49 & & & \\
\hline \multirow{3}{*}{ No. of Forests } & Between groups & 222602.983 & 6 & 37100.497 & 169.340 & $<0.001 *$ \\
\hline & Within groups & 9420.797 & 43 & 219.088 & & \\
\hline & Total & 232023.780 & 49 & & & \\
\hline \multirow[t]{3}{*}{ No. of Fish and Wildlife Areas } & Between groups & 23103.343 & 6 & 3850.557 & 1.946 & 0.095 \\
\hline & Within groups & 85066.977 & 43 & 1978.302 & & \\
\hline & Total & 108170.320 & 49 & & & \\
\hline \multirow[t]{3}{*}{ Total Acreage } & Between groups & $3.5 \mathrm{E}+12$ & 6 & $5.763 \mathrm{E}+11$ & 2.323 & 0.050 \\
\hline & Within groups & $1.1 \mathrm{E}+13$ & 43 & $2.480 \mathrm{E}+11$ & & \\
\hline & Total & $1.4 \mathrm{E}+13$ & 49 & & & \\
\hline \multirow[t]{3}{*}{ No. of Trails } & Between groups & 3391222.303 & 6 & 565203.717 & 13.873 & $<0.001 *$ \\
\hline & Within groups & 1751936.197 & 43 & 40742.702 & & \\
\hline & Total & 5143158.500 & 49 & & & \\
\hline \multirow[t]{3}{*}{ Total miles of Trails } & Between groups & $5.0 \mathrm{E}+0.7$ & 6 & 8300186.603 & 4.260 & $<0.002 *$ \\
\hline & Within Groups & $8.4 \mathrm{E}+07$ & 43 & 1948326.811 & & \\
\hline & Total & $1.3 \mathrm{E}+08$ & 49 & & & \\
\hline
\end{tabular}

Significance level at $\alpha=0.01$

As shown in Table 2 and 3, the results showed that among 12 property characteristics, eight characteristics were significantly different from each other among the 50 state park systems. These defining property characteristics were: (1) number of properties, (2) number of state parks, (3) number of recreation areas, (4) number of environmental areas, (5) number of scientific areas, (6) number of forests, (7) number of trails and (8) miles of trails.

Table 4 reports the significant and defining factors among the characteristics of amenities within these state park systems. All of the four measures of amenities for visitors: (1) number of cabins, (2) number of lodges, (3) number of restaurants and (4) number of golf courses-were significant descriptors. Table 5 shows the results of the significant descriptors among the visitor characteristics. The number of day users and the number of overnight users were the significant descriptors.

All of the operational characteristics were significant descriptors, as demonstrated in Table 6 and Table 7. These eight significant operational characteristics included: (1) total operation budget, (2) total annual revenue, (3) revenue from general funds, (4) revenue from dedicated funds, (5) total capital expenditure, (6) revenue from entry fees, (7) revenue from concessions and (8) types of dedicated funds.

Three of four characteristics of personnel or employment patterns within these state park systems were significant, as shown in Table 8. Full-time central office personnel, part-time central office personnel and full-time field positions were significant descriptors. 
Am. J. Environ. Sci., 5 (2): 187-196, 2009

Table 4: ANOVA Source Table for State Park Amenities $(\mathrm{N}=50)$

\begin{tabular}{|c|c|c|c|c|c|c|}
\hline & & Sum of squares & df & Mean square & $\mathrm{F}$ & Sig. \\
\hline \multirow[t]{3}{*}{ Number of cabins } & Between groups & 694819.823 & 6 & 115803.304 & 13.158 & $<0.001 *$ \\
\hline & Within groups & 378432.097 & 43 & 8800.746 & & \\
\hline & Total & 1073251.920 & 49 & & & \\
\hline \multirow[t]{3}{*}{ Number of lodges } & Between groups & 430.003 & 6 & 71.667 & 15.220 & $<0.001 *$ \\
\hline & Within groups & 202.477 & 43 & 4.709 & & \\
\hline & Total & 632.480 & 49 & & & \\
\hline \multirow[t]{3}{*}{ Number of estaurants } & Between groups & 1335.004 & 6 & 222.501 & 27.999 & $<0.001 *$ \\
\hline & Within groups & 341.716 & 43 & 7.947 & & \\
\hline & Total & 1676.720 & 49 & & & \\
\hline \multirow[t]{3}{*}{ Number of golf ourses } & Between Groups & 626.063 & 6 & 104.344 & 19.684 & $<0.001^{*}$ \\
\hline & Within groups & 227.937 & 43 & 5.301 & & \\
\hline & Total & 854.000 & 49 & & & \\
\hline
\end{tabular}

Table 5: ANOVA source table for visitor characteristics $(\mathrm{N}=50)$

\begin{tabular}{|c|c|c|c|c|c|c|}
\hline & & Sum of squares & $\mathrm{df}$ & Mean square & $\mathrm{F}$ & Sig. \\
\hline \multirow[t]{3}{*}{ Number of day users } & Between groups & $8.4 \mathrm{E}+15$ & 6 & $1.407 \mathrm{E}+15$ & 14.832 & $<0.001 *$ \\
\hline & Within groups & $4.1 \mathrm{E}+15$ & 43 & $9.487 \mathrm{E}+13$ & & \\
\hline & Total & $1.3 \mathrm{E}+16$ & 49 & & & \\
\hline \multirow[t]{3}{*}{ Number of night users } & Between groups & $6.1 \mathrm{E}+13$ & 6 & $1.009 \mathrm{E}+13$ & 11.416 & $<0.001^{*}$ \\
\hline & Within groups & $3.8 \mathrm{E}+13$ & 43 & $8.835 \mathrm{E}+11$ & & \\
\hline & Total & $9.9 \mathrm{E}+13$ & 49 & & & \\
\hline
\end{tabular}

Significance level at $\alpha=0.01$

Table 6: ANOVA source table for operational characteristics (Group A) $(N=50)$

\begin{tabular}{|c|c|c|c|c|c|c|}
\hline & & Sum of squares & df & Mean square & $\mathrm{F}$ & Sig. \\
\hline \multirow[t]{3}{*}{ Total operation budget } & Between groups & $9.3 \mathrm{E}+16$ & 6 & $1.545 \mathrm{E}+16$ & 61.052 & $<0.001 *$ \\
\hline & Within groups & $1.1 \mathrm{E}+16$ & 43 & $2.531 \mathrm{E}+14$ & & \\
\hline & Total & $1.0 \mathrm{E}+17$ & 49 & & & \\
\hline \multirow[t]{3}{*}{ Total annual revenue } & Between groups & $7.4 \mathrm{E}+15$ & 6 & $1.225 \mathrm{E}+15$ & 22.929 & $<0.001 *$ \\
\hline & Within groups & $2.3 \mathrm{E}+15$ & 43 & $5.343 \mathrm{E}+13$ & & \\
\hline & Total & $9.6 \mathrm{E}+15$ & 49 & & & \\
\hline \multirow[t]{3}{*}{ Revenue from general funds } & Between groups & $2.0 \mathrm{E}+16$ & 6 & $3.397 \mathrm{E}+15$ & 22.348 & $<0.001 *$ \\
\hline & Within groups & $6.5 \mathrm{E}+15$ & 43 & $1.520 \mathrm{E}+14$ & & \\
\hline & Total & $2.7 \mathrm{E}+16$ & 49 & & & \\
\hline \multirow[t]{3}{*}{ Revenue from dedicated funds } & Between groups & $4.0 \mathrm{E}+15$ & 6 & $6.603 \mathrm{E}+14$ & 25.673 & $<0.001 *$ \\
\hline & Within groups & $1.1 \mathrm{E}+15$ & 43 & $2.572+13$ & & \\
\hline & Total & $5.1 \mathrm{E}+15$ & 49 & & & \\
\hline
\end{tabular}

Significance level at $\alpha=0.01$

Table 7: ANOVA source table for operational characteristics (Group B) $(\mathrm{N}=50)$

\begin{tabular}{|c|c|c|c|c|c|c|}
\hline & & Sum of squares & $\mathrm{df}$ & Mean square & $\mathrm{F}$ & Sig. \\
\hline \multirow[t]{3}{*}{ Total capital expenditure } & Between groups & $1.0+16$ & 6 & $1.714+15$ & 11.545 & $<0.001^{*}$ \\
\hline & Within groups & $6.4+15$ & 43 & $1.485+14$ & & \\
\hline & Total & $1.7 \mathrm{E}+16$ & 49 & & & \\
\hline \multirow[t]{3}{*}{ Revenue from entry fees } & Between groups & 56429.177 & 6 & 9404.863 & 13.882 & $<0.001 *$ \\
\hline & Within groups & 29131.403 & 43 & 677.474 & & \\
\hline & Total & 85560.580 & 49 & & & \\
\hline \multirow[t]{3}{*}{ Revenue from concessions } & Between groups & $1.9 \mathrm{E}+14$ & 6 & $3.122 \mathrm{E}+13$ & 18.578 & $<0.001^{*}$ \\
\hline & Within groups & $7.2+13$ & 43 & $1.680 \mathrm{E}+12$ & & \\
\hline & Total & $2.6 \mathrm{E}+14$ & 49 & & & \\
\hline \multirow[t]{3}{*}{ Types of dedicated funds } & Between groups & 291.629 & 6 & 48.605 & 5.273 & $<0.001^{*}$ \\
\hline & Within groups & 396.391 & 43 & 9.218 & & \\
\hline & Total & 688.020 & 49 & & & \\
\hline
\end{tabular}

Significance level at $\alpha=0.01$ 
Am. J. Environ. Sci., 5 (2): 187-196, 2009

Table 8: ANOVA source table for personnel/employment patterns $(\mathrm{N}=50)$

\begin{tabular}{|c|c|c|c|c|c|c|}
\hline & & Sum of squares & df & Mean square & $\mathrm{F}$ & Sig. \\
\hline \multirow{3}{*}{$\begin{array}{l}\text { Full-time central } \\
\text { office personnel }\end{array}$} & Between Groups & 76262.720 & 6 & 12710.453 & 35.581 & $<0.001^{*}$ \\
\hline & Within groups & 15360.560 & 43 & 357.222 & & \\
\hline & Total & 91623.280 & 49 & & & \\
\hline \multirow{3}{*}{$\begin{array}{l}\text { Part-time central } \\
\text { office personnel }\end{array}$} & Between groups & 5614.251 & 6 & 935.709 & 400.478 & $<0.001 *$ \\
\hline & Within groups & 100.469 & 43 & 2.336 & & \\
\hline & Total & 5714.720 & 49 & & & \\
\hline \multirow[t]{3}{*}{ Full-time field positions } & Between groups & 2020744.951 & 6 & 336790.825 & 6.850 & $<0.001 *$ \\
\hline & Within groups & 2114289.369 & 43 & 49169.520 & & \\
\hline & Total & 4135034.320 & 49 & & & \\
\hline \multirow[t]{3}{*}{ Part-time field positions } & Between groups & 83650.757 & 6 & 13941.793 & 2.034 & 0.082 \\
\hline & Within groups & 294803.963 & 43 & 6855.906 & & \\
\hline & Total & 378454.720 & 49 & & & \\
\hline
\end{tabular}

Significance level at $\alpha=0.01$

In summary, among the 30 and 25 characteristics were significant descriptors for distinguishing differences among clusters and five characteristics were not significant. The characteristics that did not contribute to the distinction among clusters were: (1) Number of natural areas, (2) Number of historical areas, (3) Number of fish and wildlife areas, (4) Total acreage and (5) Part-time field positions. In addition, as indicated earlier, the mission of the respective state park system and the agency of oversight for the system were found not to be significant in distinguishing among the clusters.

\section{DISCUSSION}

In the United States, long-standing dialogues exist about the significance of (1) The unit in which a state parks system is housed and (2) The influence of a wellarticulated mission statement on agency function and success. This research indicates that neither of these two factors is important in defining the actual operation of a state park system.

It appears as though the reality of a given management approach is dependent upon the realities 'in the field' -infrastructure requirements, maintenance demands and staffing and budget limitations rather than a well-intentioned mission statement. If this is the case, it seems as though management has two options. First, if mission statements are to be more than guiding platitudes, they must be openly reflected in field decisions and actions. Thus, it would be important to continually educate and re-educate field staff about the mission statement and its intended impact in operations. Further, if a mission statement is to have an influence on decisions and actions in the field, staff will have to be made accountable for making decisions and taking actions in ways that clearly reflect the stated mission.

The second approach would be to acknowledge a mission statement as a public relations device, perhaps one that captures the over-arching goal of a park system in such a way as to be communicated to the public. At the same time, it would be important for management to recognize and acknowledge the physical, staffing and fiscal demands of a park system as the driving forces behind the management and operation of a park system.

In addition to learning what factors do not impact approaches to park management, this research presents a model that provides a basis for differentiation and integration of factors that define park systems. This model provides evidence for the elements of the human-nature interactions we see in environmental science. These include park amenities, users and staff (who presumably facilitate interactions between visitors and the environment), as well as the environmental factors such as property characteristics. By considering the factors that 'clump' and differentiate park systems, we offer a sound foundation for comparison-benchmarking, which is becoming increasingly important to administering entities.

Further, environmental modification (i.e., development of amenities) is frequently irreversible. Yet it is that environmental modification that tends to define and classify a park system. Management must evaluate their planning for environmental modification in light of effects such development has on delivery of services, attraction of visitors and longterm impact on important resources within a specific state. 


\section{CONCLUSION}

State parks have become important locations in which people interact with nature. In addition, these interactions between people and their environments have become important factors in sustaining quality of life, in sustaining economic health in various communities and in managing natural environments for present use while conserving them for future generations. While the various state park systems have similar roots in history and purpose, they have matured into quite disparate management systems.

Since state parks are public domain, these properties should be clearly identified in marketing available to the public. With the variety of state agencies and legal mandates for state parks, at least a portion of the public perception of state parks is based on mission and vision statements combined with title of the oversight agency. This research can assist with clarifying the marketing of state parks by providing definitive statements of the characteristics present in a given state park system. For people familiar with state parks in multiple states, a comparative clustering would also be helpful.

The legislative mandates on which these state park systems are based vary, but those mandates are not the distinguishing factors between the systems. The governmental agencies under which these systems operated vary, but those administrative homes are not the distinguishing factors between systems. However, state park systems should show a higher correlation between reality of management and the mission statements utilized. This research may assist by identifying variance between operation in practice and mission statements. Management can then more clearly focus on the desired emphasis by reducing that variance.

\section{REFERENCES}

1. Aldenderfer, M.S. and R.K. Blashfield, 1984. Cluster Analysis. 1st Edn., Sage Publications, Newbury Park, CA., ISBN: 10: 0803923767, pp: 88.

2. Conard, R., 1997. Places of Quiet Beauty: Parks, Preserves and Environmentalism. University of Iowa Press, Iowa City, IA., ISBN: 10: 0877455589. pp: 400.

3. Caparn, H.A., 1931. State Parks, Supplement to National Municipal Review. In: A State Park Anthology, Evison, H. (Ed.). Mount Pleasant Press, Harrisburg, PA., pp: 35-41.
4. Douglass, R.W., 1999. History of Outdoor Recreation and Nature-Based Tourism in the United States. In: Outdoor Recreation in American life: A National Assessment of Demand and Supply Trends, Cordell, H.K. (Ed.). Sagamore Publishing, Champaign, IL., ISBN: 10: 157167246X, pp: 499.

5. Edginton, C.R., D.J. Jordan, D.G. Degraaf and S.R. Ed, 2002. Leisure and Life Satisfaction: Foundational Perspectives. 3rd Edn., McGraw Hill, New York, USA., ISBN: 10: 0072489170, pp: 596.

6. Hartigan, J.A., 1975. Clustering Algorithms. 99th Edn., John Wiley and Sons, Inc., New York, ISBN: 047135645X, pp: 366.

7. Landrum, N.C., 1999. America's State Parks-An End-of-Century Assessment. In: Outdoor Recreation in American Life: A National Assessment of Demand and Supply Trends, Cordell, H.K. (Ed.). Sagamore Publishing, Champaign, IL., pp: 112-115.

8. Landrum, N.C., 2004. The State Park Movement in America: A critical review. 1st Edn., University of Missouri Press. Columbia, MO., ISBN: 10: 0826215009, pp: 304.

9. Mackintosh, B., 1999. The national park service: A brief history.

http://www.nps.gov/history/history/hisnps/npshisto ry/briefhistory.htm

10. McLean, D.D., 1999. State Park Systems in the United States. In: Outdoor Recreation in American Life: A National Assessment of Demand and Supply Trends, Cordell, H.K. (Ed.). Sagamore Publishing, Champaign, IL., pp: 107-112.

11. McLean, D.D., D. Chavez and J.S. Knapp, 1999. An 8-year analysis of state park fiscal trends. State Park Research Report 99-1. State Park Information Resources Center, Bloomington, IN. http://cuacs8.mck.ncsu.edu/naspd/research/sprr/rr9 9-1.pdf

12. Myers, P., 1989. State Parks in a New Era; Volume 2-Future Directions in Funding. The Conservation Foundation, Washington DC., ISBN: 0891641114, pp: 61.

13. Sharpe, G..W., C.H. Odegaard and W.F. Sharpe, 1994. A Comprehensive Introduction to Park Management. 2nd Edn., Sagamore Publishing Champaign, IL., ISBN: 10: 0915611589, pp: 400.

14. Tilden, F., 1962. The State Parks: Their Meaning in American Life. 1st Edn., Knopf, New York, pp: 496. 